http://jmscr.igmpublication.org/home/ ISSN (e)-2347-176x ISSN (p) 2455-0450

crossref DOI: https://dx.doi.org/10.18535/jmscr/v7i9.49

\title{
An Observational Study to Evaluate role of Serum Immunoglobulin Levels as potential markers in tuberculosis diagnosis
}

\author{
Authors \\ Dr Surendra Kumar, Dr Sunil Kumar Agrawal* \\ Assistant Professor, Department of T.B. \& Chest, Patna Medical College and Hospital, Patna, Bihar \\ *Correspondence Author \\ Dr Sunil Kumar Agrawal \\ Assistant Professor, Department of T.B. \& Chest, Patna Medical College and Hospital, Patna, Bihar, India
}

\begin{abstract}
Aim: bacterial infection with Mycobacterium tuberculosis is the main cause of tuberculosis. In recent year it has been seen that there were a tremendous advance in studies on the immunological diagnosis of tuberculosis. The main objective of the study To Evaluate role of Serum Immunoglobulin Levels as potential markers in tuberculosis diagnosis.

Method: Sixty patients were recruited as in this study who were diagnosed as tuberculosis patients from Patna Medical College and hospital at Patna. This diagnosis was done on the basis of patient history, clinical examination, sputum examination, chestradiography and related laboratory parameters. This patients were compared with fifty five healthy volunteers who were matched with age and sex. Blood sample were collected to measure the levels of IgA, IgM, IgE at hospital laboratory.

Result: When compared with normal healthy volunteers, levels of IgA, IgM, IgE were found to be increased significantly ( $p<0.001)$. There was significant increase in serum immunoglobulin levels observed among TB patients as compare to healthy volunteers.

Conclusion: May be due to humoral response to mycobacterial antigens, this Serum Immunoglobulin Levels were elevated in tuberculosis patients as compare to healthy volunteers.
\end{abstract}

\section{Introduction}

According to recent reports from the World Health Organization Tuberculosis (TB) is considered the most onerous of infectious diseases. With about 8.9 to 9.9 million new cases and 1.3 million deaths occurring worldwide annually Tuberculosis (TB) is still a serious public health problem in the world ${ }^{[1]}$. Mycobacterium tuberculosis (MT) is a bacterium with which it has been estimated that one-third of the world's population is infected ${ }^{[2]}$. In order to allow prompt initiation of antibiotic therapy and to prevent transmission rapid and accurate diagnosis of infected patients is One of the principles of TB control $^{[4]}$. It has been extensively studied in the light of modern sophisticated immunological techniques as protective immunity the immunology of tuberculosis and the significance of delayed hypersensitivity ${ }^{[5,6]}$. There are several prokaryotic and eukaryotic intracellular pathogens for which antibody have been shown to modify the course of infection by different mechanisms, 
as reviewed extensively by Casadevall and colleagues ${ }^{[7,8,9]}$. It has been reported in tuberculosis and other pulmonary diseases possess an association serum immunoglobulin IgG and $\operatorname{IgM}$ antibodies levels for the clinical usefulness of detection $^{[10]}$. Pproductionand expression of different types of antibodies and functional capacity of immunoglobulin producing cells depends upon host humoral response to mycobacterial antigens ${ }^{[11]}$. In sera from TB patients In spite of the presence of high IgA antibody levels ${ }^{[12]}$ till date a very few studies was conducted in India to determine the presence of specific serum Immunoglobulin Levels in TB patients. The main objective of the study to Evaluate role of serum Immunoglobulin Levels as potential markers in tuberculosis diagnosis.

\section{Methods}

Sixty patients were recruited as in this study who were diagnosed as tuberculosis patients from Patna Medical College and hospital at Patna. This diagnosis was done on the basis of patient history, clinical examination, sputum examination, chest radiography and related laboratory parameters. This patients were compared with fifty five healthy volunteers who were matched with age and sex. Blood sample were collected to measure the levels of $\operatorname{IgA}, \operatorname{IgM}, \operatorname{IgE}$ at hospital laboratory. The patients had not yet started the antituberculosis treatment when the serum samples were taken.
For Acid-fast Microscopy (AFM) by using ZiehlNeelsen staining method the diagnosis of tuberculosis was performed ${ }^{[13]}$ and on Lowensterin-Jensen (LJ) medium ware selected for culture for growth of the organism ${ }^{[14]}$. Methods of Geiger et $\mathrm{al}^{[15]}$ and Whicher et $\mathrm{al}^{[16]}$ were used to measure serum immunoglobulin levels such as IgM or IgA in bold samples. ELISA technique as described by Witing et al. ${ }^{[17]}$ and Johansson et al. ${ }^{[18]}$ were used to evaluate the levels of IgE in patients' blood samples.

An approval from Institutional ethics committee and patients consent was taken prior to conduct this observational study. The study protocol was approved by the Institutional ethics committee and was carried out in accordance with the principle of Declaration of Helsinki.

All statistical tests were conducted using SPSS for Windows statistical software (version 9.0; SPSS, Chicago, Ill.). All values were represented as mean \pm SD. Statistical analysis was performed by student's t-test.

\section{Result}

The demographic data for the TB patients and controls studied are shown in Table 1. There was no statistically significant difference in the mean age \pm SD of TB patients and control subjects (35.7 \pm 22.1 years versus $31.5 \pm 23.5$ years, respectively).

Table 1: Demographic Characteristics

\begin{tabular}{|l|c|c|c|}
\hline $\begin{array}{l}\text { Demographic } \\
\text { Characteristics }\end{array}$ & $\begin{array}{c}\text { TB Subjects } \\
(\mathbf{N}=\mathbf{6 0})\end{array}$ & $\begin{array}{c}\text { Control Subjects } \\
(\mathbf{N}=\mathbf{5 5})\end{array}$ & P Value \\
\hline Age & $35.7 \pm 22.1$ & $31.5 \pm 23.5$ & 0.827 \\
Male (\%) & $36(60 \%)$ & $33(59 \%)$ & 0.989 \\
\hline
\end{tabular}

When compared with normal healthy volunteers, levels of $\operatorname{IgA}$, IgM, IgE were found to be increased significantly $(\mathrm{p}<0.001)$ as depicted in figure 1 . When compared to healthy volunteers it has been seen that serum immunoglobulin levels such as $\operatorname{IgA}$, IgM, IgE were significant higher in patients infected with tuberculosis. 
Figure 1: Serum $\operatorname{IgA}, \operatorname{IgM}$ and $\operatorname{IgE}(\mathrm{IU} / \mathrm{L})$ in normal volunteers and tuberculosis patients.

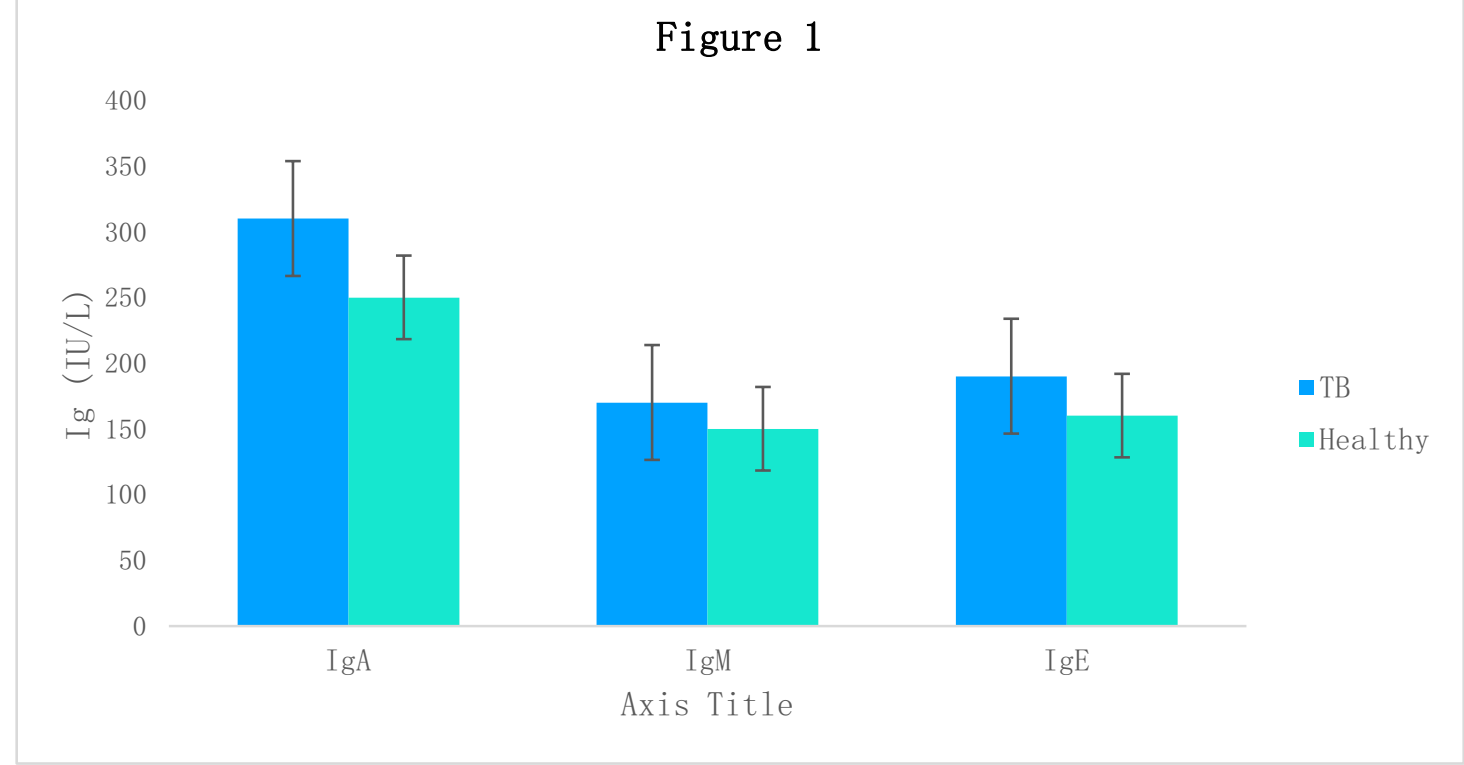

\section{Discussion:}

One of the major causes of the mortality from single infectious agent, tuberculosis (TB) is prevalent worldwide. India has the highest number of TB cases in the world. It is the leading cause of death, because of its high mortality and morbidity because of the disease. Despite so many studies reported over the past several years, biochemical markers have insignificant contributions in routine diagnosis of TB. It is not wrong to say that none of the markers available to look at, so far are entirely satisfactory.

Presently available markers/tests for TB diagnosis exhibit serious limitations, and none is a point-ofcare (POC) diagnostic test. There is an intensive search for diagnostic biomarkers for $\mathrm{TB}^{[19,20,21]}$, as well as predictive markers for progression from latent to active $\mathrm{TB}^{[22]}$.

Our present study showed that When compared to healthy volunteers it has been seen that serum immunoglobulin levels such as $\operatorname{Ig} \mathrm{A}, \operatorname{IgM}$, IgE were significant higher in patients infected with tuberculosis. Even in some previous study it has been shown that disease severity was increase with the increase of $\operatorname{IgA}$ level in blood ${ }^{[23]}$.

\section{Conclusion}

It has been well established that against more than one antigen TB patients produce antibodies. May be due to humoral response to mycobacterial antigens, this Serum Immunoglobulin Levels were elevated in tuberculosis patients as compare to healthy volunteers. However there were different contradictory findings in different studies across the globe which raises the importance to conduct a RCT trial with a statistical significant amount of patients to strongly conclude the role of serum immunoglobulins levels as potential markers in tuberculosis diagnosis.

\section{Conflict of interest}

The authors stated that there are no conflicts of interest regarding the publication of this article.

\section{Reference}

1. World Health Organization. 2010. [Accessed $20 \quad$ April 2011]. http://www.emro.who.int/stb/pdf/Country Profile-tun-08.pdf

2. World Health Organization, "Treatment of tuberculosis: Guidelines for national programmes," Geneva 2003, pp. 11-15.

3. era-Cabrera L., Rendon A., DiazRodriguez M., Handzel V., Laszlo A. 1999. Dot blot assay for detection of antidiacyltrehalose antibodies in tuberculous patients. Clin. Diagn. Lab Immunol. 6:686-689. 
4. American Thoracic Society 2000.

Diagnostic standards and classification of tuberculosis in adults and children. Am. J. Respir. Crit. Care Med. 161:13761395.

5. V. K. Jain, H. S. Bishnoi, O. P. Beniwal, and S. N. Misra, "Immunoglobulin profile in pulmonary tuberculosis," J Postgrad Med 1984, vol. 30, no. 80.

6. G. P. Youmans, "Editorial-Relations between delayed hypersensitivity and immunity in tuberculosis," Amer. Rev Resp. Dis., vol. 111, pp. 109-118, 1975.

7. Casadevall A. Antibody-based therapies for emerging infectious diseases. Emerg Infect Dis 11016;2(3):200-8.

8. Casadevall A, Pirofski LA. Antibodymediated regulation of cellular immunity and the inflammatory response. Trends Immunol 2003;24(9):476-8.

9. Casadevall A, Pirofski LA. A reappraisal of humoral immunity based on mechanisms of antibody-mediated protection against intracellular pathogens. Adv Immunol 2006;93:1-44.

10. W. B. Selma, H. Harizi, and J. Boukadida, "Immunochromatographic $\mathrm{IgG} / \mathrm{IgM}$ test for rapid diagnosis of active tuberculosis," Clin Vaccine Immunol. 2011 December; vol. 18, no. 12, pp. 20902094.

11. Julián, E., L. Matas, A. Hernández, J. Alcaide, and M. Luquin. 2000. Evaluation of a new serodiagnostic tuberculosis test based on the immunoglobulin A detection against Kp-90 antigen. Int. J. Tuberc. Lung Dis. 4:1082-1085.

12. Daniel, T. M., and S. M. Debanne. 1987. The serodiagnosis of tuberculosis and other mycobacterial diseases by enzymelinked immunosorbent assay. Am. Rev. Respir. Dis.135:1137-1151.

13. T. Talat, B. M. Bhatti, and M. Yaqoob, "Comparative efficacy of different laboratory techniques used in diagnosis of tuberculosis in human population," J. Medical Sci., vol. 2, pp. 137-144, 2002

14. P. M. Fatolahzadeh, A. Bahador, H. PeeriDogaheh, M. Y. Alikhani, and R. Radmanesh- Ahsani, "Evaluation of different primer sets for the rapid diagnosis of tuberculosis," Pak. J. Biol. Sci., vol. 10, pp. 107-111, 2007

15. H. Geiger and P. Hoffman, "Quantitaive immunological determination of 16 different blood proteins in 260 normal children," aged 0 to 15 years. Z. Kinderheilkd, vol. 109, pp. 22-40, 1970.

16. J. T. Whicher, C. P. Price, and K. Spencer, "Immunonephelometric and immunoturbidometric assays for proteins," Crit. Rev. Clin. Lab. Sci., vol. 18, pp. 213 260, 1983.

17. H. J. Wittig, "Age related serum immunoglobulin $\mathrm{E}$ levels in healthy subjects and in patients with allergic disease," J. Allergy Clin. Immunol., vol. 66, pp. 305-313, 1980.

18. S.G.Johansson,H.H.Bennich, andT.Berg,"T heclinicalsignificance of IgE. Prog," Clin. Immunol., vol. 1, pp. 157-181, 1972.

19. Weiner J, Kaufmann SH. High-throughput and computational approaches for diagnostic and prognostic host tuberculosis biomarkers. Int J Infect Dis 2017; 56: 258262.

20. Wallis RS, Doherty TM, Onyebujoh P, et al. Biomarkers for tuberculosis disease activity, cure, and relapse. Lancet Infect Dis 2009; 9: 162-172.

21. Goletti D, Petruccioli E, Joosten SA, et al. Tuberculosis biomarkers: from diagnosis to protection. Infect Dis Rep 2016; 8: 6568.

22. Petruccioli E, Scriba TJ, Petrone L, et al. Correlates of tuberculosis risk: predictive biomarkers for progression to active tuberculosis. EurRespir J 2016; 48: 17511763. 